\title{
Seasonal variability of phenolic compounds and antioxidant activity in prickly pear cladodes of Opuntia and Nopalea genres
}

\author{
Francisco Abel Lemos ALVES ${ }^{1 \star}$, Albericio Pereira de ANDRADE², Riselane de Lucena Alcântara BRUNO²,
} Maria Goretti de Vasconcelos SILVA ${ }^{4}$, Maria de Fátima Vanderlei de SOUZA ${ }^{5}$, Djalma Cordeiro dos SANTOS ${ }^{6}$

\begin{abstract}
The prickly pear is a cactaceae that have chemical compounds that act as natural antioxidants. In addition, the prickly pear is a plant widely used in semiarid region as it's considered very important forage for animal feed, especially in the dry season. The objectives of this research were to characterize the main classes of phytochemicals, determine the phenols content, flavonoids and anthocyanins and evaluate the antioxidant activity of the prickly pear cultivars Opuntia and Nopalea grown in the semiarid region of Pernambuco in two collection periods (dry and rainy). In the work crude ethanol extracts from cladodes of cultivars (IPA-20, Elephant Ear Mexican, F-08, V-19, Small palm, F-21 and IPA-Sertânia) were used. As for the class of phytochemical compounds from ethanol extract only the flavonoids and steroids were detected in all prickly pear cultivars, in both periods analyzed. The content of phenolic compounds ranges from 1.24 to $5.41 \mathrm{mg} \mathrm{GAE} \mathrm{g}^{-1} \mathrm{DM}$, flavonoids 0.90 to $3.43 \mathrm{mg} \mathrm{QE} \mathrm{g}^{-1} \mathrm{DM}$, anthocyanins from 0.05 to $0.34 \mu \mathrm{g}$ QE $100 \mathrm{~g}^{-1} \mathrm{DM}$ and antioxidant activity 39.59 to $217.17 \mu \mathrm{M}$ TEAC $\mathrm{g}^{-1} \mathrm{DM}$. The occurrence of chemical variability and antioxidant activity were observed, both among the botanical cultivars studied and among the collection periods.
\end{abstract}

Keywords: biodiversity and nutrition; cactus pear; flavonoids; phenolic acids; phytochemicals.

Practical Application: Use of cladodes of prickly pear cultivars as functional foods in the diet human and animal.

\section{Introduction}

The Opuntia spp. and Nopalea spp. are grown in the semiarid region of northeastern Brazil, as basic food support of ruminants, especially in the dry season. It is estimated that the area of species Opuntia ficus indica and Nopalea cochenillifera cultivated in Brazil is 600.000 ha. This region is characterized by having a high index of annual evaporation, approximately $2,000 \mathrm{~mm}$, and an average of $750 \mathrm{~mm}$ rainfall, concentrated in a period of three to five months (Araújo et al., 2005).

The prickly pear is a cactaceous adapted to drought conditions, it has morphophysiological mechanisms which absorb water of little rainfall and reduce water loss by transpiration. Thus, by virtue of these characteristics, it is adapted to arid and semiarid zones, where water is a limiting factor in agricultural production and livestock (Oliveira et al., 2010).

In recent years the interest in chemical studies associated with prickly pear cladodes has increased, studies have revealed that the antioxidant activity of aqueous extracts is attributed mainly to phenols and flavonoids (Guevara-Figueroa et al., 2010; Santos-Zea et al., 2011; Astello-García et al., 2015).

The species of the genus Opuntia and Nopalea presents a broad genetic diversity, thus there is a need to characterize the cultivars grown in the northeastern region of Brazil in order to get phytochemical information and bioactive properties (Alves et al., 2016a). The objectives of this research were to characterize the main classes of phytochemicals, determine the content of phenols, flavonoids and anthocyanins and evaluate the antioxidant activity of prickly pear cultivars of the Opuntia and Nopalea genres grown in semiarid region of Pernambuco in two collection periods (dry and rainy).

\section{Materials and methods}

\subsection{Plant material}

In the present research, three year old cladodes of the cultivars of prickly pear were collected in the experimental station of the Agronomic Institute of Pernambuco (IPA), located in the county of Arcoverde-PE, Brazil. The materials used are listed in Table 1.

Secondary and tertiary cladodes of each cultivars were collected in the dry and rainy period, from six plants, at 8:00 am. After collection, the material was cleaned, weighed, cut into small pieces $\left(2-3 \mathrm{~cm}\right.$ long) and dried in a forced-air oven at $55^{\circ} \mathrm{C}$, where it remained for $72 \mathrm{hs}$ until constant weight. The dried

${ }^{1}$ Experimental Station of Caruaru, Instituto Agronômico de Pernambuco - IPA, Caruaru, PE, Brazil

${ }^{2}$ Academic Unit of Garanhus, Universidade Federal Rural de Pernambuco - UFRPE, Garanhus, PE, Brazil

${ }^{3}$ Department of Plant and Environmental Sciences, Centre of Agricultural Sciences, Universidade Federal da Paraíba - UFPB, Areia, PB, Brazil

${ }^{4}$ Department of Analytical and Physical-Chemistry, Science Center, Universidade Federal do Ceará - UFC, Fortaleza, CE, Brazil

${ }^{5}$ Department of Pharmaceutical Science, Health Sciences Centre, Universidade Federal da Paraíba - UFPB, João Pessoa, PB, Brazil

${ }^{6}$ Experimental Station of Arcoverde, Instituto Agronômico de Pernambuco - IPA, Arcoverde, PE, Brazil

*Corresponding author: abel.alves@ipa.br 
Table 1. Prickly pear cultivars, of Opuntia and Nopalea genres used in the research.

\begin{tabular}{cccc}
\hline $\mathrm{N}^{\circ}$ & Cultivars & Specie & Usual name \\
\hline 1 & IPA 100003 & $\begin{array}{c}\text { Opuntia ficus } \\
\text { indica }\end{array}$ & IPA-20 \\
2 & IPA 200016 & $\begin{array}{c}\text { Opuntia stricta } \\
\text { Elephant Ear } \\
\text { Mexican }\end{array}$ & F-08 \\
3 & IPA 200008 & $\begin{array}{c}\text { Opuntia atropes } \\
\text { Opuntia larreri } \\
4\end{array}$ & V-19 \\
5 & IPA 200149 & IPA 100004 & Small palm \\
6 & IPA 200021 & $\begin{array}{c}\text { Nopalea } \\
\text { cochenillifera } \\
\text { Nopalea } \\
\text { cochenillifera }\end{array}$ & F-21 \\
7 & IPA 200205 & IPA-Sertânia \\
\hline
\end{tabular}

material was crushed in Willey ${ }^{\circledR}$ type mill and packed into sealed plastic pots (Alves et al., 2016b).

\subsection{Ethanol extraction}

The extraction of the dry and crushed material (10 g) was performed with $95 \%$ ethanol at room temperature, covering the entire sample with the solvent following methodologies described in Alves et al. (2016b).

\subsection{Phitochemical prospecting}

For the identification of alkaloids, steroids, tannins, flavonoids and saponins was used sample of crude ethanolic extract (1 mg) following methodologies described in Alves et al. (2016b).

\subsection{Determining total phenolics content}

The total phenolics content was determined in crude ethanol extracts in triplicate by spectrophotometric method using the Folin-Ciocateau reagent (Gulcin et al., 2004), with changes in dosages. Initially, an aliquot of $300 \mu \mathrm{L}$ of the extract $\left(5 \mathrm{mg} \mathrm{mL}^{-1}\right.$ in ethanol) was transferred into test tubes, to which $60 \mu \mathrm{L}$ of Folin-Ciocalteu reagent along with an aliquot of 2,460 $\mu \mathrm{L}$ of distilled water were added and stirred for $60 \mathrm{~s}$. Then $180 \mu \mathrm{L}$ of $\mathrm{Na}_{2} \mathrm{CO}_{3}$ $15 \%$ solution was added and stirred again for $30 \mathrm{~s}$, resulting in a final solution of $0.5 \mathrm{mg} \mathrm{mL}^{-1}$. The reaction mixture was allowed to stand for $30 \mathrm{~min}$ at $45^{\circ} \mathrm{C}$ in the absence of light. The reading of absorbance at $760 \mathrm{~nm}$ was recorded employing a Shimadzu ${ }^{\circledR}$ UV-VIS spectrophotometer UV-2550. A standard curve with gallic acid ( 1 to $15 \mu \mathrm{g} \mathrm{mL}^{-1}$ ) was obtained under the same conditions. The results were expressed in $\mathrm{mg}$ of GAE (gallic acid equivalent) per gram of dry mass (mg GAE g $\left.{ }^{-1} \mathrm{DM}\right)$.

\subsection{Determining the total flavonoid content}

The total flavonoids content was determined in the raw ethanol extracts, in triplicate, by the method described by Pereira et al. (2009), with changes in dosages. Initially, $5 \mathrm{~mL}$ aliquot of the extract ( $2 \mathrm{mg} \mathrm{mL}^{-1}$ in methanol) was transferred to $10 \mathrm{~mL}$ volumetric flasks and $0.5 \mathrm{~mL}$ of $2 \%$ aluminum chloride methanolic solution were added and the volume completed with $5 \%$ acetic acid methanolic solution, for $30 \mathrm{~min}$ at room temperature in the absence of light. The reading of absorbance at $425 \mathrm{~nm}$ was recorded employing a UV-VIS spectrophotometer Femto $^{\circledR}$ model 700 plus. A standard curve with quercetin ( 1 to $200 \mu \mathrm{g} \mathrm{mL} \mathrm{mL}^{-1}$ ) was obtained under the same conditions. The results were expressed in $\mathrm{mg}$ of $\mathrm{QE}$ (quercetin equivalent) per gram of dry mass (mg QE g-1 DM).

\subsection{Determining the total Anthocyanin content}

The anthocyanin content was determined in crude ethanolic extract in triplicate by the method described by Lemos (2008). In a $50 \mathrm{~mL}$ Erlenmeyer flask a foil coated sample of $0.5 \mathrm{~g}$ (crude extract) in $20 \mathrm{~mL}$ of extraction solution (95\% ethanol in 1.5 mol. $\left.\mathrm{L}^{-1} \mathrm{HCl}\right)\left(85: 15\right.$, v. $\left.^{-1}\right)$ were homogenized and stored for $18 \mathrm{hs}$ at $4^{\circ} \mathrm{C}$. Samples were completed with the extraction solution for volumetric flasks of $25 \mathrm{~mL}$, coated with aluminum foil and the reading of absorbance at $535 \mathrm{~nm}$ was recorded using a spectrophotometer UV-vis from Femto ${ }^{\circledR}$, model 700 plus. The results were expressed in $\mu \mathrm{g}$ of (QE) (quercetin equivalent) per 100 gram dry weight ( $\mu \mathrm{g}$ QE. $100 \mathrm{~g}^{-1} \mathrm{DM}$ ).

To quantify the total anthocyanins, the following Formula 1 was used:

Total anthocyanins $\left(\boldsymbol{\mu g}\right.$ of $\left.\mathbf{Q E} \mathbf{g}^{-\mathbf{1}}\right)=A 535 . F d \cdot 10 / \bar{E}$

where: $A 535=$ absorbance at $535 \mathrm{~nm}$;

$\overline{\mathrm{E}}=765$ (molar extinction coefficient for Quercetin 1\%) at $535 \mathrm{~nm}$;

$F d=$ Dilution factor.

\subsection{Determination of total antioxidant activity}

The ability to scavenge the radical 2,2'-azinobis-(3-ethylbenzothiazoline-6-sulfonic acid ABTS*+) was determined according to the method described by Rufino et al. (2007). The radical ABTS ${ }^{*+}$ is generated from the reaction of the aqueous solution of ABTS $\left(7 \mathrm{mmol} . \mathrm{L}^{-1}\right)$ with potassium persulfate $\left(140 \mathrm{mmol} . \mathrm{L}^{-1}\right)$. The solution was kept from light, at room temperature for $16 \mathrm{hs}$. Then the solution was diluted with ethanol until absorbance of $0.70 \pm 0.05 \mathrm{~nm}$ at wavelength of $734 \mathrm{~nm}$. The concentrations of 200,300 and $400 \mathrm{mg} \mathrm{L}^{-1}$ of the ethanol extracts were added to the $\mathrm{ABTS}^{*+}$ solution, and the absorbance recorded after $6 \mathrm{~min}$ in a UV-vis spectrophotometer from Femto ${ }^{\circledR}$, model 700 plus. The antioxidant activity was calculated relative to the antioxidant Trolox activity (6-hydroxy2,5,7,8-tetramethylchromane-2-carboxylic acid), under the same conditions, and the results expressed in equivalent antioxidant Trolox capacity ( $\mu$ mol. $\left.\mathrm{L}^{-1} \mathrm{TEAC} \mathrm{g}^{-1} \mathrm{DM}\right)$.

\subsection{Statistical analysis}

The experimental design utilized was randomized blocks, with seven treatments, represented by the cultivars with three replications. The experimental plots consisted of two plants. The analysis were performed in triplicate and results were expressed in mean \pm standard deviation. After analysis of data variance, means were compared by the Scott-Knott test at $5 \%$ probability using the program Assistat ${ }^{\circledR} 7.7$ beta (Silva \& Azevedo, 2009). 


\section{Results and discussion}

\subsection{Phytochemical prospecting}

The phytochemical prospecting of cultivars of prickly pear during the dry and rainy period are presented in Table 2. The flavonoids and steroids was detected in all cultivars in the dry and rainy period. The tannins was detected in V-19 cultivate in the dry period, and in cultivars IPA-20, Elephant Ear Mexican, IPA-Sertânia in the rainy period.

The presence of flavonoids, steroids and tannins on cladodes of prickly pear (Opuntia spp.) was reported by Brás (2011), Bari et al. (2012), Mendez et al. (2012) and Soares (2012), collaborating with our results.

In addition to the detection of tannins and flavonoids, Bari et al. (2012) and Mendez et al. (2012) detected the presence of saponins and alkaloids. Therefore was used several reagents for the detection of alkaloids in the samples. Since, many alkaloids precipitate in reactions involving inorganic ions and sometimes the reaction with a specific ionic reagent is not sufficient to detect your presence (Desoti et al., 2011). The non-detection of these classes of phytochemical compounds in Opuntia cladodes is probably related to temperature-time damage in the chemical composition of the samples, once the cladodes were dried at $55{ }^{\circ} \mathrm{C}$ for $72 \mathrm{hs}$. Some studies report the effect of temperature-time on the degradation of phytochemical compounds (Palermo et al., 2014).

The prospecting for tannins and flavonoids of the prickly pear cultivars possibly indicate variability between the genotypes and collection periods, since the intensity of the color was different between the genotypes and collection periods (Table 2). The response of the cultivars to the flavonoids was more intense in the rainy period, except V-19, which obtained the highest amount of flavonoids in the dry period.
Abiotic stresses (drought, salinity, heat, ultraviolet radiation) are the main environmental factors that negatively affect the growth and development of cultures in semiarid regions of the world (Ramakrishna \& Ravishankar, 2011). Furthermore, the biotic stress (attack by fungi, bacteria, viruses, nematodes, mites, animals) can also cause reduction in the growth and development of cultures in these regions. Thus, for the plants to survive in these regions they developed structures based on anatomical features and/or chemical related biologically diverse molecular mass of active compounds (Soares \& Machado, 2007).

The secondary metabolites of the class of phenolic compounds, terpenes and nitrogen compounds act to protect against damage caused by pests and environmental stresses. These molecules act as toxic and repellent substances for pests, besides they act in the osmotic adjustment and protection against reactive oxygen species (ROS), furthermore they act in the stabilization of cell membranes and proteins of plant exposed to abiotic stresses (Ramakrishna \& Ravishankar, 2011; Rodziewicz et al., 2014). So the greater production and/or accumulation of phenolic compounds was observed in the rainy period as a way to protect the plant against water stress in the dry period, and protect the plant against the attack of the carmine cochineal (Dactylopius opuntiae) that is a pest that is decimating the palms in the states of Pernambuco, Paraíba, Rio Grande do Norte and Ceará (Lima et al., 2011).

\subsection{Phenolic content and total flavonoids}

The results of the phenolic content and total flavonoids of prickly pear cultivars are presented in Figure 1. The content of phenolic compounds in the prickly pear cladodes varied significantly between cultivars and between periods of material collection. In dry period the values ranged from $1.24 \mathrm{mg} \mathrm{GAE} \mathrm{g}^{-1}$ DM (IPA-Sertânia) to $2.85 \mathrm{mg} \mathrm{GAE} \mathrm{g}^{-1} \mathrm{DM}$ (IPA-20) (Figure 1a)

Table 2. Phytochemical prospecting of cultivars of prickly pear during the dry and rainy periods.

\begin{tabular}{|c|c|c|c|c|c|c|c|c|c|c|}
\hline \multirow[b]{2}{*}{ Cultivars } & \multicolumn{4}{|c|}{ Alkaloides } & \multirow{2}{*}{$\begin{array}{c}\text { Steroids } \\
\text { (Liebermann-Burchard) }\end{array}$} & \multicolumn{2}{|c|}{ Tannins } & \multicolumn{2}{|c|}{ Flavonoids } & \multirow{2}{*}{$\begin{array}{c}\text { Saponins } \\
\text { Foam }\end{array}$} \\
\hline & 1 & 2 & 3 & 4 & & $\begin{array}{c}\text { Gelatine } \\
0.5 \%\end{array}$ & $\begin{array}{c}\mathrm{FeCl} 3 \\
2 \%\end{array}$ & $\begin{array}{c}\text { Magnesium -tape } \\
\text { (Shinoda) }\end{array}$ & $\begin{array}{c}\text { Fluorescence } \\
\text { (Taubouk) }\end{array}$ & \\
\hline \multicolumn{11}{|c|}{ Dry period } \\
\hline IPA-20 & - & - & - & - & + & - & - & + & ++ & - \\
\hline Elephant Ear Mexican & - & - & - & - & + & - & - & + & ++ & - \\
\hline F-08 & - & - & - & - & + & - & - & ++ & ++ & - \\
\hline $\mathrm{V}-19$ & - & - & - & - & + & + & + & ++ & +++ & - \\
\hline Small palm & - & - & - & - & + & - & - & + & + & - \\
\hline F-21 & - & - & - & - & + & - & - & + & ++ & - \\
\hline IPA-Sertânia & - & - & - & - & + & - & - & + & ++ & - \\
\hline & \multicolumn{10}{|c|}{ Rainy period } \\
\hline IPA-20 & - & - & - & - & + & - & + & +++ & +++ & - \\
\hline Elephant Ear Mexican & - & - & - & - & + & + & + & +++ & +++ & - \\
\hline F-08 & - & - & - & - & + & - & - & +++ & +++ & - \\
\hline $\mathrm{V}-19$ & - & - & - & - & + & - & - & ++ & ++ & - \\
\hline Small palm & - & - & - & - & + & - & - & +++ & +++ & - \\
\hline F-21 & - & - & - & - & + & - & - & +++ & +++ & - \\
\hline IPA-Sertânia & - & - & - & - & + & - & + & +++ & +++ & - \\
\hline
\end{tabular}

1. Bouchardat, 2. Mayer, 3. Dragendorf, 4. Bertrand; “+++” (high intensity), “++” (medium intensity), “+” (low intensity), “-“ (negative reaction). 

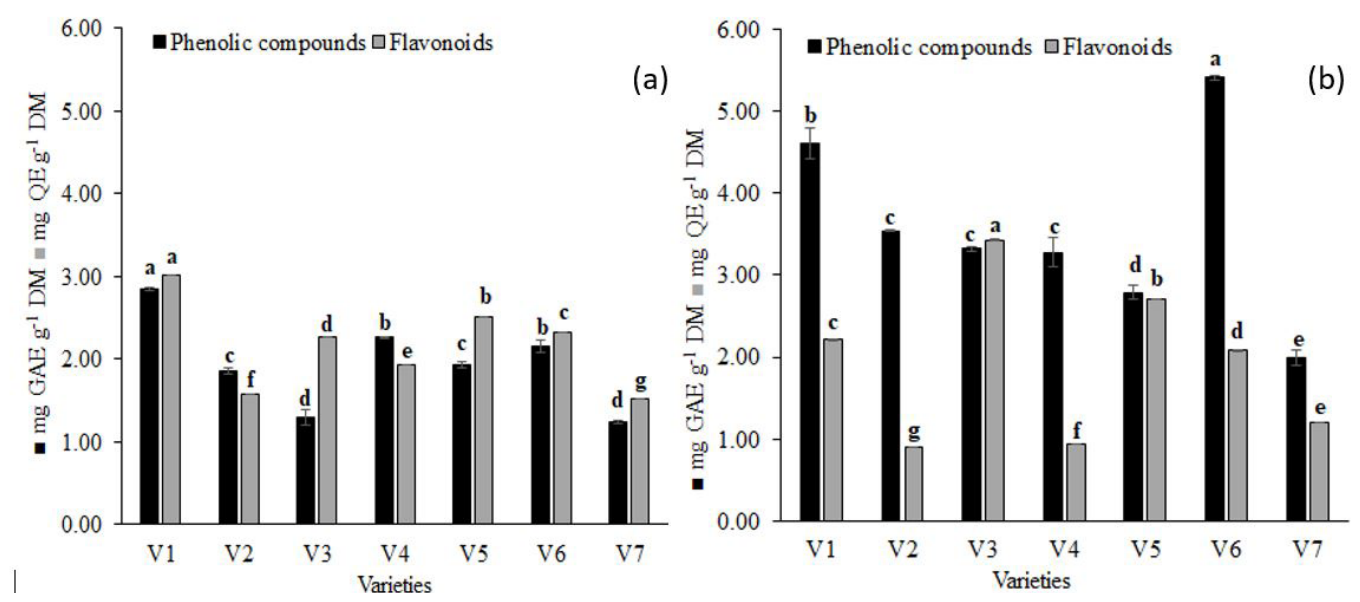

Figure 1. Phenolics and total flavonoids content of prickly pear cultivars. (a) dry period; (b) rainy period. V1. IPA-20, V2. Elephant Ear Mexican, V3. F-08, V4. V-19, V5. Small palm, V6. F-21 and V7. IPA-Sertânia. Means followed by the same letter in columns black or grey are not statistically different from each other. Scott-Knott test at $5 \%$ probability was applied. The bars represent the mean $(n=3) \pm$ standard deviation.

and in rainy period ranged from $1.99 \mathrm{mg} \mathrm{GAE} \mathrm{g}^{-1}$ (IPA-Sertânia) to $5.41 \mathrm{mg} \mathrm{GAE} \mathrm{g}^{-1} \mathrm{DM}$ (F-21) (Figure 1b).

The values found in this work for total phenolics are above those described by Santos-Zea et al. (2011) and Corral-Aguayo et al. (2008) studying ten cultivars of prickly pear, (Opuntia spp.) grown in Mexico, with values ranging from 0.14 to $0.91 \mathrm{mg} \mathrm{GAE} \mathrm{g}^{-1} \mathrm{DM}$. However, Guevara-Figueroa et al. (2010) and Bensadón et al. (2010) researching cultivars of commercial and wild prickly pear grown in Mexico reported the variation of phenolic total to be from 2.00 to $37.10 \mathrm{mg} \mathrm{GAE} \mathrm{g}^{-1} \mathrm{DM}$.

The low values of total phenolic reported in this and in study of Santos-Zea et al. (2011) compared with the reported values per Guevara-Figueroa et al. (2010) and Bensadón et al. (2010), is probably related to the effect of temperature-time of drying of the material on the degradation of chemical compounds (Palermo et al., 2014).

In the rainy period the content of phenolic compounds among the cultivars (Figure 1) was superior to the dry period values, ranging from $44 \%$ (small palm) to $157 \%$ (F-08). The variation of phenolic compounds between the collection period or season (spring, summer and winter) in O. ficus indica (variety Aissa) and O. megacantha (variety Achefri), grown in Ouled Dlim (Marrakech, Morocco), was reported by Boutakiout et al. (2017). The authors reported that the content of phenolic is higher in the summer (dry period).

Like the phenolic, the total flavonoid in prickly pear cladodes varied $(p<0.05)$ among cultivars and between periods of collecting material. The values ranged from $1.53 \mathrm{mg} \mathrm{QE} \mathrm{g}^{-1} \mathrm{DM}$ (IPA-Sertânia) to $3.02 \mathrm{mg} \mathrm{QE} \mathrm{g}^{-1} \mathrm{DM}$ (IPA-20) (dry period); and $0.90 \mathrm{mg} \mathrm{QE} \mathrm{g}^{-1} \mathrm{DM}$ (Elephant Ear Mexican) to $3.43 \mathrm{mg} \mathrm{QE} \mathrm{g}^{-1}$ DM (F-08) (rainy period) (Figure 1).

The values found in this work for the total flavonoids are in agreement with those described by Guevara-Figueroa et al. (2010) studying (Opuntia spp.) prickly pear cultivars
(2.00 to $9.80 \mathrm{mg} \mathrm{QE} \mathrm{g}^{-1} \mathrm{DM}$ ) and Bari et al. (2012) researching O. monacantha (4.44 $\mathrm{mg} \mathrm{QE} \mathrm{g}^{-1} \mathrm{DM}$ ).

Unlike the phenolics the flavonoids among the cultivars was higher in the dry period, except for F-08 and small palm which had higher values in the rainy period. This variation was $7.5 \%$ (small palm) to $51.4 \%$ (V-19) (Figure 1).

The total phenols and flavonoids in plants have a wide range, both in composition and content, and vary between species and within species. The factors that contribute to these differences in the Opuntia genus are genetic variability and edafoclimatic conditions (Bari et al., 2012; Santos-Zea et al., 2011).

The prickly pear cultivars of the genus Opuntia and Nopalea used in this work were grown under the same edafoclimatic conditions, then the differences in the amount of secondary metabolites (phenolic compounds) should be related to each species biochemical characteristics. Astello-García et al. (2015) also reported differences in the accumulation of total phenolic contents of fifteen cultivars of five Opuntia species, with varied domestication gradients. This variation occurred among the botanical cultivars and among the species studied, and was dependent of the biochemical characteristics of each species, since these plants were grown in identical edafoclimatic conditions.

The significant differences between the cultivars was expected, considering that it comes from plant materials which have different phenotypic characteristics. The difference between the collection periods (dry and rainy) for flavonoids and phenolic compounds in tomato cultivars (Solanum lycopersicum) was reported by Sánchez-Rodríguez et al. (2011, 2012). The total phenolic compounds in tomato cultivars are higher in period rainy, while total flavonoid are superior in period dry, corroborating with the results found in this work.

The flavonoids are commonly classified by Sánchez-Rodríguez et al. (2012) as "environmental compounds" as they are produced in response to environmental conditions (ultraviolet light, water stress, salt stress, low temperatures, nutrient deficit 
(N, K, P, S, Mg and Fe), high $\mathrm{CO}_{2}$ levels). Tavarini et al. (2011) describe that water stress induces increased synthesis of phenolic compounds in peach (Prunus persica) fruits.

However, the availability of water increases the phenolic compounds in tomato cultivars (Barbagallo et al., 2008) and barley (Bandurska et al., 2012). The mechanisms that regulate this influence are not completely clear, and there is variability in responses between species and cultivars.

Most studies report that the content of total phenolic compounds is greater than the total flavonoids, since the flavonoids correspond to a class of phenolic compounds. These results differ from those described in the literature since the flavonoid content in the dry period exceeded those of the phenolic compounds, for most cultivars studied. Potentially the phenolic compounds from the group of flavonoids are the molecules most produced when plants are under drought stress.

Studying Opuntia spp. Guevara-Figueroa et al. (2010), Santos-Zea et al. (2011) and Bari et al. (2012) highlighted the cultivars (Blanco, Tapon-I, Tapon-II, Jalpa, Gavia, Villanueva) as having higher total flavonoid content in relation to the total phenolic, confirming the results presented in this work.

The flavonoid biosynthesis, isoflavones and anthocyanins are stimulated by environmental stresses, mainly drought. The flavonoids have a protective function in plants exposed to water stress, because of its antioxidant properties by eliminating ROS and maintain turgor and stabilize cell membranes and proteins (Rodziewicz et al., 2014). The oxidation products of flavan-3-ols (flavanols) is increased under drought stress in Camellia sinensis (Hernández et al., 2006). Furthermore, the water stress increases the level of quercetin, rutin, and 1-5-dihidroxixantona in Hypericum brasiliense. The increase of these compounds probably indicates a response to the generation of ROS caused by water stress (Abreu \& Mazzafera, 2005).

\subsection{Total anthocyanin content}

The contents of anthocyanins in the prickly pear cultivars in dry and rainy periods are presented in Figure 2. Significant variation of the contents of anthocyanin was observed among cultivars and between periods of material collection is observed. In the dry period, the values ranged from $0.05 \mu \mathrm{g}$ QE $100 \mathrm{~g}^{-1}$ DM (Elephant Ear Mexican) to $0.34 \mu \mathrm{g} \mathrm{QE} 100 \mathrm{~g}^{-1} \mathrm{DM}$ (V-19); and in the rainy period from $0.12 \mu \mathrm{g} Q E 100 \mathrm{~g}^{-1} \mathrm{DM}$ (Elephant Ear Mexican) to $0.26 \mu \mathrm{g}$ QE $100 \mathrm{~g}^{-1} \mathrm{DM}$ (F-21).

Contrary to what happened to the total flavonoids, the anthocyanin content was superior for all cultivars in the rainy period, except for $\mathrm{V}-19$, the cladodes stood out in this determination compared to the other treatments, reaching the highest levels of anthocyanins in the dry period. This variation was $29.4 \%$ (IPA-20) to $271.4 \%$ (F-21) (Figure 2). Generally the reduction in water addition increases the content of phenolic compounds and anthocyanins in plants, since these molecules act against water stress (Bandurska et al., 2012).

Anthocyanins, secondary metabolites of the flavonoid class are responsible for color ranging from red to violet and white to light yellow. They can be found in all plant tissues, including leaves, roots, stems, fruits and flowers (Lemos, 2008). In literature there are no studies related to quantification of total anthocyanins in the genus Opuntia. In this genre the betalains, secondary metabolites of the alkaloid class, are often cited, with the same extraordinary range of colors ranging from lime green, orange, red purple (Yahia \& Mondragon-Jacobo, 2011).

\subsection{Total antioxidant activity}

The results of determination of the antioxidant activity of prickly pear cultivars in dry and rainy periods are in Figure 3. The total antioxidant activity in prickly pear cladodes varied significantly between the cultivars and between periods of material collection. In the dry period, the values ranged

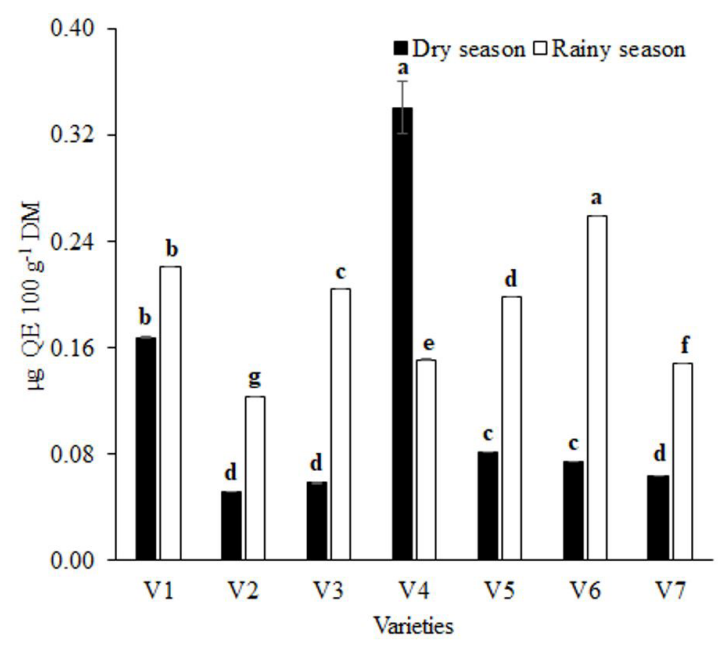

Figure 2. Determination of Anthocyanins in prickly pear cultivars in the dry and rainy period. V1. IPA-20, V2. Elephant Ear Mexican, V3. F-08, V4. V-19, V5. Small palm, V6. F-21 and V7. IPA-Sertânia. Means followed by the same letter in black or white columns do not differ statistically from each other. Scott-Knott test at $5 \%$ probability was applied. The bars represent the mean $(n=3) \pm$ standard deviation.

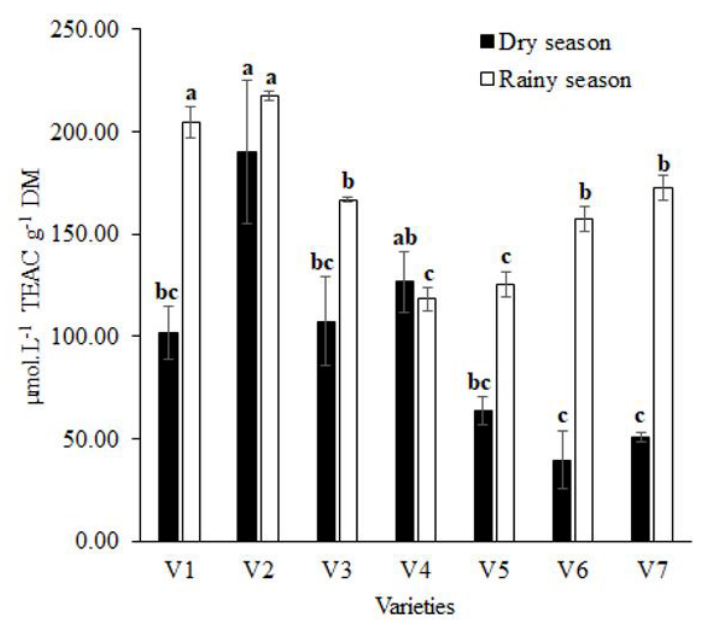

Figure 3. Determination of the total antioxidant activity in the dry and rainy period prickly pear cultivars. V1. IPA-20, V2. Elephant Ear Mexican, V3. F-08, V4. V-19, V5. Small palm, V6. F-21 and V7. IPA-Sertânia. Means followed by the same letter in black or white columns do not differ statistically from each other. Scott-Knott test at $5 \%$ probability was applied. The bars represent the mean $(n=3) \pm$ standard deviation. 

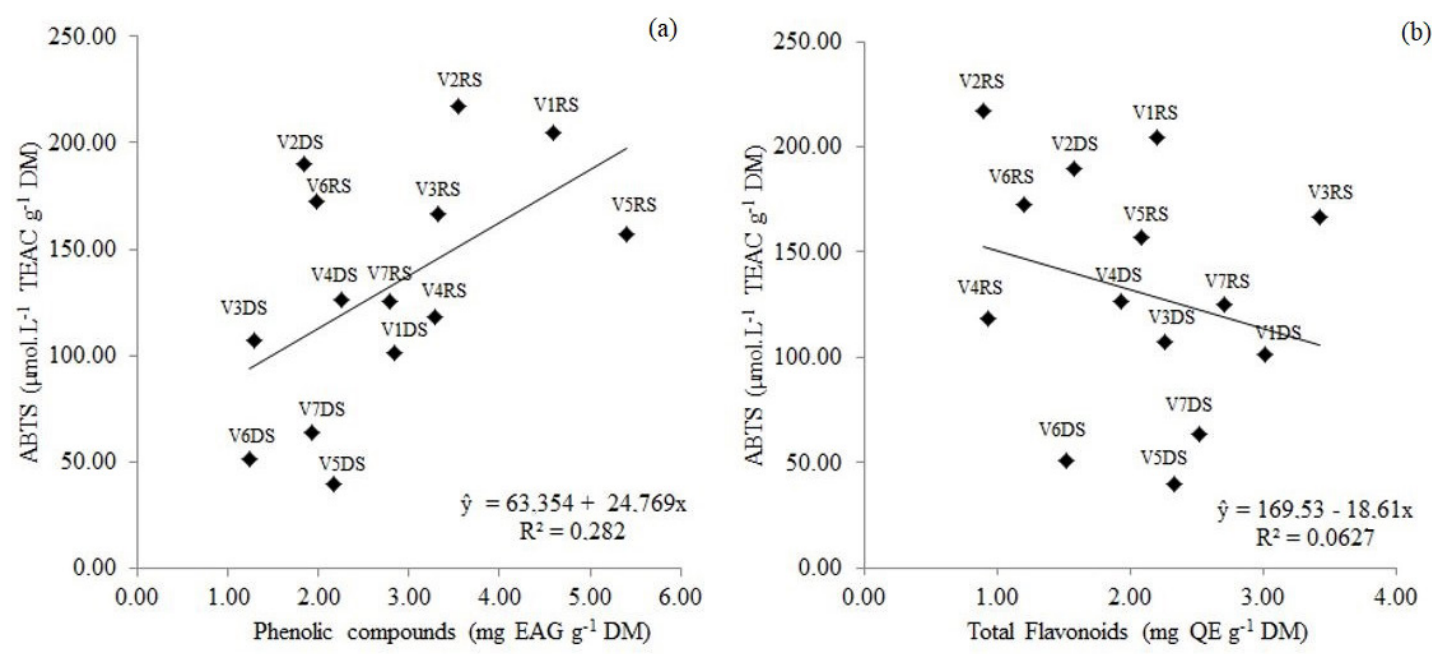

Figure 4. Correlation between total antioxidant activity and content of phenolic compounds (a) and / or total flavonoid (b) of prickly pear cultivars. V1. IPA-20, V2. Elephant Ear Mexican, V3. F-08, V4. V-19, V5. Small palm, V6. F-21 and V7. IPA-Sertânia. DS: dry season. RS: rainy season.

from $39.59 \mu$ mol.L-1 $\mathrm{TEAC}^{-1} \mathrm{DM}(\mathrm{F}-21)$ to $189.85 \mu \mathrm{mol} \cdot \mathrm{L}^{-1}$ TEAC g ${ }^{-1} \mathrm{DM}$ (Elephant Ear Mexican); and in the rainy period, from $118.06 \mu$ mol. $L^{-1}$ TEAC g ${ }^{-1} \mathrm{DM}$ (V-19) to $217.17 \mu \mathrm{mol}^{-\mathrm{L}^{-1}}$ TEAC g $^{-1}$ DM (Elephant Ear Mexican) (Figure 3).

The antioxidant capacity among the cultivars was higher in the rainy period, except for V-19, which had the highest value in the dry period. Despite the difference found between the periods in relation to the antioxidant capacity, this variation was not significant between the Elephant Ear Mexican cultivars and V-19. In general, the variation in antioxidant capacity between the periods was $6.7 \%$ (V-19) at $296.8 \%$ (F-21) (Figure 3).

Bensadón et al. (2010), Santos-Zea et al. (2011) and CorralAguayo et al. (2008) studying the antioxidant capacity of Opuntia spp., reported values ranging from 52.37 to $770.4 \mu \mathrm{mol} \mathrm{TEAC} \mathrm{g}{ }^{-1}$ DM for cladodes. Like this work, the authors found positive correlations between antioxidant activity and phenolic content. Moreover, these authors reported that some cultivars with high total phenols values do not have the same response in the antioxidant capacity (Figure 4a). The difference is probably due to the high content of sugars and ascorbic acid found in the prickly pear cladodes, which interfere with the reaction of oxidation-reduction between the Folin and phenolic compounds.

In this work no positive correlations between total flavonoid and total antioxidant capacity (Figure 4b) were found. Potentially the majority flavonoids in the extract were in the glycosidic form, with carbohydrate fractions bound to hydroxyl group at C-3, thus losing its antioxidant activity when glycosylated, especially at C-3 (Santos-Zea et al., 2011).

Among the notable properties of polyphenols are their antioxidant activity and free radical scavenging. However, the antioxidant capacity of a food is cumulative, and acts synergistically with vitamins (ascorbic acid), polyphenols, carotenoids, betalains, anthocyanins, tocopherols, coumarins, alkaloids, phenolic acids, non-protein amino acids, sesquiterpenes, isoprene, carbohydrates, and enzymes such as superoxide dismutase (SOD), glutathione reductase (GR), glutathione peroxiase (GPX), peroxiredoxin (PRXR), catalase (CAT), ascobarte peroxidase (APX), reductase monodehidroascorbate (MDHAR), dehydroascorbate reductase (DHAR), polyphenol oxidase (PPO) (Corral-Aguayo et al., 2008; Ferreira et al., 2010; Soares \& Machado, 2007; Yahia \& Mondragon-Jacobo, 2011; Zhong et al., 2010).

In this work the antioxidant activity was determined in crude ethanolic extracts, as the individual contribution of phenolic compounds, flavonoids and anthocyanins could not be differentiated. There are several reports of the antioxidant capacity of fruits and prickly pear cladodes, correlating them with the bioactive compounds (vitamins, polyphenols, carotenoids, betalains, anthocyanins, tocopherols, carbohydrates), but the results are not consistent, some researchers report positive correlations and others find no correlation with some these bioactive compounds. Possibly the results of correlations diverge due to the different methods used in the drying and extraction of chemical compounds the sample, difference maturation stages of the sample collected, genotypic divesity of the cultivars used in the studies, edafoclimatic variation of the collection sites, among others factors.

This work help in the selection of prickly pear cultivars more nutritious. Besides that, this work contributes as reference material for addition of prickly pear cladodes in the diet as functional foods. However, more researches need to be carried to identify and quantify other bioactive molecules and correlate them with the antioxidant capacity.

\section{Conclusions}

Both the Opuntia and Nopalea genres contain flavonoids and steroids independent of the cultivars or the period (dry and rainy).

The phenolic compounds, flavonoids, anthocyanins and total antioxidant activity in cladodes of both genres vary among cultivars and between the dry and rainy periods. 


\section{Acknowledgements}

We thank to students Isabelle de Lima Brito, Maristela Alves Alcântara, Severino Gonçalves de Brito Filho, Alex da Silva Barbosa, Maria Isabel Barros Fernandes and Laís Chantelle de Lima, and teacher Dra . Iêda Maria Garcia dos Santos for the support in the obtaining data.

\section{References}

Abreu, I. N., \& Mazzafera, P. (2005). Effect of water and temperature stress on the content of active constituents of Hypericum brasiliense Choisy. Plant Physiology and Biochemistry, 43(3), 241-248. PMid:15854832. http://dx.doi.org/10.1016/j.plaphy.2005.01.020.

Alves, F. A. L., Andrade, A. P., Bruno, R. L. A., \& Santos, D. C. (2016a). Study of the variability, correlation and importance of chemical and nutritional characteristics in cactus pear (Opuntia and Nopalea). African Journal of Agricultural Research, 11(31), 2882-2892. http:// dx.doi.org/10.5897/AJAR2016.11025.

Alves, F. A. L., \& Andrade, A. P., Bruno, R. L. A., Silva, M. G. V., Souza, M. F. V., Pessoa, C., Oliveira, F. C. E., Brito, S. G. Fo., \& Santos, D. C. (2016b). Genetic diversity and seasonal chemical profile by ${ }^{1} \mathrm{H}$ NMR and cytotoxix activity in Opuntia and Nopalea genres. Journal of Medicinal Plants Research, 10(40), 732-747. http://dx.doi. org/10.5897/JMPR2016.6207.

Araújo, L. F., Oliveira, L. S. C., Perazzo-Neto, A., Alsina, O. L. S., \& Silva, F. L. H. (2005). Equilíbrio higroscópico da palma forrageira: Relação com a umidade ótima para fermentação sólida. Revista Brasileira de Engenharia Agrícola e Ambiental, 9(3), 379-384. http:// dx.doi.org/10.1590/S1415-43662005000300013.

Astello-García, M. G., Cervantes, I., Nair, V., Santos-Díaz, M., \& Reyes-Agüero, A., Guéraud, F., Negre-Salvayre, A., Rossignol, M., Cisneros-Zevallos, L., \& Barba de la Rosa, A. P. (2015). Chemical composition and phenolic compounds profile of cladodes from Opuntia spp. cultivars with different domestication gradiente. Journal of Food Composition and Analysis, 43(1), 119-130. http:// dx.doi.org/10.1016/j.jfca.2015.04.016.

Bandurska, H., Pietrowska-Borek, M., \& Cieslak, M. (2012). Response of barley seedlings to water deficit and enhanced UV-B irradiation acting alone and in combination. Acta Physiologiae Plantarum, 34(1), 161-171. http://dx.doi.org/10.1007/s11738-011-0814-9.

Barbagallo, R. N., Chisari, M., Branca, F., \& Spagna, G. (2008). Pectin methylesterase, polyphenol oxidase and physicochemical properties of typical long-storage cherry tomatoes cultivated under water stress regime. Journal of the Science of Food and Agriculture, 88(3), 389-396. http://dx.doi.org/10.1002/jsfa.3098.

Bari, M. N., Zubair, M., Rizwan, K., Rasool, N., Bukhari, I. H., Akram, S., Bokhari, T. H., Shahid, M., Hameed, M., \& Ahmad, V. U. (2012). Biological activities of Opuntia Monacantha cladodes. Journal of the Chemical Society of Pakistan, 34(4), 990-995.

Bensadón, S., Hervert-Hernández, D., Sáyago-Ayerdi, S., \& Goñi, I. (2010). By-products of Opuntia ficus-indica as a source of antioxidant fietary fiber. Plant Foods for Human Nutrition, 65(3), 210-216. PMid:20623195. http://dx.doi.org/10.1007/ s11130-010-0176-2.

Boutakiout, A., Elothmani, D., Hanine, H., Mahrouz, M., Le-Meurlay, D., Hmid, I., \& Ennahli, S. (2017). Effects of different harvesting seasons on antioxidant activity and phenolic content of prickly pear cladode juice. Journal of the Saudi Society of Agricultural Sciences. In press. http://doi.org/10.1016/j.jssas.2016.11.005.
Brás, A. A. Q. (2011). Caracterização do extrato de Opuntia ficus indica (L.) Mill e avaliação de sua atividade fotoprotetora (Monografia de graduação). Universidade Estadual da Paraíba, Campina Grande.

Corral-Aguayo, R. D., Yahia, E. M., Carrillo-Lopez, A., \& GonzálezAguilar, G. (2008). Correlation between some nutritional components and the total antioxidant capacity measured with six different assays in eight horticultural crops. Journal of Agricultural and Food Chemistry, 56(22), 10498-10504. PMid:18956873. http://dx.doi. org/10.1021/jf801983r.

Desoti, V. C., Maldaner, C. L., Carletto, M. S., Heinz, A. A., Coelho, M. S., Piati, D., \& Tiuman, T. S. (2011). Triagem fitoquímica e avaliação das atividades antimicrobiana e citotóxica de plantas medicinais nativas da região oeste do estado do Paraná. Arquivos de Ciência da Saúde da UNIPAR, 15(1), 3-13.

Ferreira, D. S., Rosso, V. V., \& Mercadante, A. Z. (2010). Compostos bioativos presentes em amora-preta (Rubus spp.). Revista Brasileira de Fruticultura, 32(3), 664-674. http://dx.doi.org/10.1590/S010029452010005000110.

Guevara-Figueroa, T., Jiménez-Islas, H., Reyes-Escogido, M., Mortensen, A. G., Laursen, B. B., Lin, L.-W., León-Rodríguez, A., \& Fomsgaard, I. S., \& Barba de la Rosa, A. P. (2010). Proximate composition, phenolic acids, and flavonoids characterization of commercial and wild nopal (Opuntia spp.). Journal of Food Composition and Analysis, 23(6), 525-532. http://dx.doi.org/10.1016/j.jfca.2009.12.003.

Gulcin, I., Sat, I. G., Beydemir, S., Elmastas, M. E., \& Kufrevioglu, O. I. (2004). Comparison of antioxidant activity of clove (Eugenia caryophylata Thunb) buds and lavender (Lavandula stoechas L.). Food Chemistry, 87(3), 393-400. http://dx.doi.org/10.1016/j. foodchem.2003.12.008.

Hernández, I., Alegre, L., \& Munné-Bosch, S. (2006). Enhanced oxidation of flavan-3-ols and proanthocyanidin accumulation in water stressed tea plants. Phytochemistry, 67(11), 1120-1126. PMid:16712885. http://dx.doi.org/10.1016/j.phytochem.2006.04.002.

Lemos, A. R. (2008). Caracterização físico-química, bioquímica e avaliação da atividade antioxidante em genótipos de Urucueiros (Bixa orellana L.) (Dissertação de mestrado). Universidade Estadual do Sudoeste da Bahia, Itapetinga.

Lima, M. S., Silva, D. M. P., Falcão, H. M., Ferreira, W. M., Silva, L. D., \& Paranhos, B. A. J. (2011). Predadores associados à Dactylopius opuntiae (Hemiptera: Dactylopiidae) em palma forrageira no estado de Pernambuco, Brasil. Revista Chilena de Entomologia, 36(1), 51-54.

Mendez, M., Rodríguez, R., Ruiz, J., Morales-Adame, D., Castillo, F., Hernández-Castillo, F. D., \& Aguilar, C. N. (2012). Antibacterial activity of plant extracts obtained with alternative organics solvents against food-borne pathogen bacteria. Industrial Crops and Products, 37(1), 445-450. http://dx.doi.org/10.1016/j.indcrop.2011.07.017.

Oliveira, F. T., Silva, J. S., Silva, R. P., Andrade-Filho, F. C., \& PereiraJunior, E. B. (2010). Palma forrageira: Adaptação e importância para os ecossistemas áridos e semiáridos. Revista Verde de Agroecologia e Desenvolvimento Sustentável, 5(4), 27-37.

Palermo, M., Pellegrini, N., \& Fogliano, V. (2014). The effect of cooking on the phytochemical content of vegetables. Journal of the Science of Food and Agriculture, 94(6), 1057-1070. PMid:24227349. http:// dx.doi.org/10.1002/jsfa.6478.

Pereira, A. V., Almeida, T. C., Beltrame, F. L., Costa, M. E., \& Garrido, L. H. (2009). Determinação de compostos fenólicos em amostras comerciais de chás verde e preto - Camellia sinensis (L.) Kuntze, Theaceae. Acta Scientiarum. Health Sciences, 31(2), 119-124.

Ramakrishna, A., \& Ravishankar, G. A. (2011). Influence of abiotic stress signals on secondary metabolites in plants. Plant Signaling 
\& Behavior, 6(11), 1720-1731. PMid:22041989. http://dx.doi. org/10.4161/psb.6.11.17613.

Rodziewicz, P., Swarcewicz, B., Chmielewska, K., Wojakowska, A., \& Stobiecki, M. (2014). Influence of abiotic stresses on plant proteome and metabolome changes. Acta Physiologiae Plantarum, 36(1), 1-19. http://dx.doi.org/10.1007/s11738-013-1402-y.

Rufino, M. S. M., Alves, R. E., Brito, E. S., Morais, S. M., Sampaio, C. G., Pérez-Jiménez, J. P., \& Saura-Calixto, F. D. (2007). Metodologia científica: determinação da atividade antioxidante total em frutas pela captura do radical livre ABTS ${ }^{*}$. (Embrapa Agroindústria Tropical. Comunicado Técnico, 128, 4 p.). Fortaleza: Embrapa Agroindústria Tropical.

Sánchez-Rodríguez, E., Moreno, D. A., Ferreres, F., Rubio-Wilhelmi, M. M., \& Ruiz, J. M. (2011). Differential responses of five cherry tomato varieties to water stress: changes on phenolic metabolites and related enzymes. Phytochemistry, 72(8), 723-729. PMid:21420135. http://dx.doi.org/10.1016/j.phytochem.2011.02.011.

Sánchez-Rodríguez, E., Ruiz, J. M., Ferreres, F., \& Moreno, D. A. (2012). Phenolic profiles of cherry tomatoes as influenced by hydric stress and rootstock technique. Food Chemistry, 134(2), 775-782. PMid:23107690. http://dx.doi.org/10.1016/j.foodchem.2012.02.180.

Santos-Zea, L., Gutiérrez-Uribe, J. A., \& Serna-Saldivar, S. O. (2011). Comparative analyses of total phenols, antioxidant activity, and flavonol glycoside profile of cladode flours from different varieties of Opuntia spp. Journal of Agricultural and Food Chemistry, 59(13), 7054-7061. PMid:21598948. http://dx.doi.org/10.1021/jf200944y.
Silva, F. A. S., \& Azevedo, C. A. V. (2009). Principal components analysis in the software Assistat-Statistical Attendance. In Proceedings of the 7th World Congress on Computers in Agriculture, Reno-NV-USA. http://dx.doi.org/10.13031/2013.29066.

Soares, A. M. S., \& Machado, O. L. T. (2007). Defesa de plantas: sinalização química e espécies reativas de oxigênio. Revista Trópica: Ciências Agrárias e Biológicas, 1(1), 9-19.

Soares, B. S. A. (2012). Obtenção e caracterização do extrato nebulizador da Opuntia fícus-indica (L.) Mill e avaliação da sua atividade antimicrobiana e fotoprotetora (Monografia de graduação). Universidade Estadual da Paraíba, Campina Grande.

Tavarini, S., Gil, M. I., Tomas-Barberan, F. A., Buendia, B., Remorini, D., Massai, R., Degl'Innocenti, E., \& Guidi, L. (2011). Effects of water stress and rootstocks on fruit phenolic composition and physical/ chemical quality in Suncrest peach. Annals of Applied Biology, 158(2), 226-233. http://dx.doi.org/10.1111/j.1744-7348.2010.00457.x.

Yahia, E. M., \& Mondragon-Jacobo, C. (2011). Nutritional components and anti-oxidant capacity of ten cultivars and lines of cactus pear fruit (Opuntia spp.). Food Research International, 44(7), 2311-2318. http://dx.doi.org/10.1016/j.foodres.2011.02.042.

Zhong, X.-K., Jin, X., Lai, F.-Y., Lin, Q.-S., \& Jiang, J.-G. (2010). Chemical analysis and antioxidant activities in vitro of polysaccharide extracted from Opuntia ficus indica Mill. cultivated in China. Carbohydrate Polymers, 82(3), 722-727. http://dx.doi.org/10.1016/j. carbpol.2010.05.042. 